Aspirasi: Jurnal Masalah-Masalah Sosial | Volume 9, No, 2 Desember 2018

ISSN: 2086-6305 (print) ISSN: 2614-5863 (electronic)

DOI: https://doi.org/10.22212/aspirasi.v7il.1084

link online: http://jurnal.dpr.go.id/index.php/aspirasi/index

\title{
MASYARAKAT SADAR BENCANA: PEMBELAJARAN DARI KARO, BANJARNEGARA, DAN JEPANG
}

\author{
Disaster Awareness Society: Lesson Learned from Karo, Banjarnegara and Japan
}

\author{
Rohani Budi Prihatin \\ rohani.prihatin@dpr.go.id \\ Pusat Penelitian Badan Keahlian DPR RI \\ Jl. Gatot Subroto Senayan Jakarta
}

Naskah Diterima: 10 Oktober 2018 | Naskah direvisi: 4 Desember 2018 | Naskah diterbitkan: 30 Desember 2018

\begin{abstract}
Geographical location, archipelago, large population, and tropical climate have placed Indonesia as a high disaster risk area. How Indonesia anticipates and handles natural disasters is a very important problem to be studied, especially related to the process of public awareness to disasters from these two case studies, namely the Mount Sinabung Eruption in Karo, North Sumatra and landslides in Banjarnegara, Central Java. By conducting in-depth interviews, field observations, and literature studies, this study found the fact that the strategies used in managing natural disasters in Indonesia, especially in terms of disaster awareness, had been reactive. Even though most people are still alive and looking for life in the midst of high-risk areas, in fact they are not really prepared for disaster. In the case of the Sinabung disaster there seems to be no tradition of Karo community preparedness in the face of disasters after a long time since Mount Sinabung was inactive. Conversely, in the case of disasters in Banjarnegara, this awareness has grown even though it has not been as ideal as Japanese society. This proves that most victims still use fatalistic views in facing disasters. Most victims are not afraid to return to their original place which was once a disaster area. This lack of awareness is influenced by the perspective of most people who accept what nature has given and see natural disasters as an inevitable fate.
\end{abstract}

Keywords: disaster awareness society, adaptation, capacity building, Sinabung, Banjarnegara

\begin{abstract}
Abstrak: Lokasi geografis, wilayah kepulauan, populasi yang besar, dan kondisi iklim tropis telah menempatkan Indonesia sebagai daerah dengan risiko bencana tinggi. Bagaimana Indonesia mengantisipasi dan menangani bencana-bencana alam tersebut menjadi masalah yang sangat penting untuk dipelajari, khususnya terkait dengan proses kesadaran masyarakat terhadap bencana dari dua studi kasus Letusan Gunung Sinabung di Karo, Sumatera Utara dan tanah longsor di Banjarnegara, Jawa Tengah. Melalui penelitian kualitatif yang dilakukan dengan wawancara mendalam, observasi lapangan, dan studi pustaka, penelitian ini menemukan fakta bahwa strategi yang digunakan dalam mengelola bencana alam di Indonesia, terutama dari sisi sadar bencana, selama ini masih bersifat reaktif. Meskipun kebanyakan orang masih hidup dan mencari kehidupan di tengah-tengah daerah berisiko tinggi, sebenarnya mereka tidak benar-benar siap menghadapi bencana. Pada kasus bencana Sinabung tampak tidak ada tradisi kesiapsiagaan masyarakat Karo dalam menghadapi bencana setelah sekian lama Gunung Sinabung tidak aktif. Sebaliknya, pada kasus bencana di Banjarnegara, telah tumbuh kesadaran tersebut walau belum seideal pada masyarakat Jepang. Hal ini membuktikan bahwa kebanyakan korban masih menggunakan pandangan fatalistik dalam menghadapi bencana. Mayoritas korban tidak takut untuk kembali ke tempat asal mereka yang dulunya merupakan daerah bencana. Kurangnya kesadaran ini dipengaruhi oleh perspektif masyarakat kebanyakan yang menerima apa yang diberikan alam dan
\end{abstract}


melihat kejadian bencana alam sebagai takdir yang tak terelakkan.

Kata kunci: masyarakat sadar bencana, adaptasi; pembangunan kapasitas, Sinabung, Banjarnegara

\section{Pendahuluan}

Dalam beberapa tahun belakangan, bencana yang disebabkan oleh alam maupun nonalam semakin meningkat, baik dari sisi karakteristik maupun tingkat risikonya. Meningkatnya kerusakan lingkungan akibat peningkatan kegiatan eksploitasi alam menjadi pemicu peningkatan risiko terjadinya bencana tersebut. Secara umum, bencana alam merupakan sebuah peristiwa merugikan yang dihasilkan dari proses alami perputaran planet bumi (Bankoff, 2003). Contohnya adalah banjir, badai, letusan gunung berapi, gempa bumi, tsunami, dan proses-proses geologi lainnya. Akibat bencana alam adalah hilangnya nyawa, cedera atau sakit, rusaknya properti, hilangnya pendapatan keluarga, serta berdampak psikologis.

Berdasarkan data pada peta dunia di Gambar 1, warna yang lebih gelap (seperti Kanada, Arab Saudi, Mesir, Mongolia, dan sebagian besar Eropa Barat) menunjukkan kejadian bencana yang sangat rendah, kejadian bencana yang rendah (USA, Rusia, dan lainnya), kejadian bencana yang sedang (China, Afrika Selatan, dan lainnya). Sedangkan kejadian bencana yang tinggi (seperti Indonesia), dan kejadian bencana yang sangat tinggi (seperti Nigeria, Jepang, dan lainnya). Indonesia berdasarkan gambar di atas masuk masuk dalam kategori tinggi.

Berdasarkan data Worldwatch Institute, pada tahun 2012 terjadi 905 bencana alam di seluruh dunia dan 93\% di antaranya merupakan bencana yang berhubungan dengan cuaca. Berdasarkan penelitian Ikhuoria dkk (2012), data bencana alam menunjukkan bahwa banjir dan angin ribut menempati urutan teratas di seluruh dunia. Sementara itu, banjir merupakan bencana yang paling sering dan paling luas dampaknya terhadap kehidupan ekonomi, bisnis, infrastruktur, pelayanan, dan kesehatan masyarakat. Hal yang sama juga terjadi di Indonesia.

Pada tahun 2005, UNESCO menempatkan Indonesia di urutan ketujuh dalam daftar negaranegara paling rawan di dunia. Berbagai bencana datang silih berganti dan menimbulkan korban serta kerugian yang tidak sedikit jumlahnya. Setiap tahun tercatat ribuan orang meninggal dunia, luka-luka, terpaksa mengungsi dari tempat tinggalnya, serta banyak lagi kerugian lain yang diakibatkan oleh bencana. Oleh karena itu, menjadi agenda penting bagi masyarakat Indonesia untuk mengetahui, memahami, dan menyadari bahwa bumi merupakan wilayah yang rawan bencana.

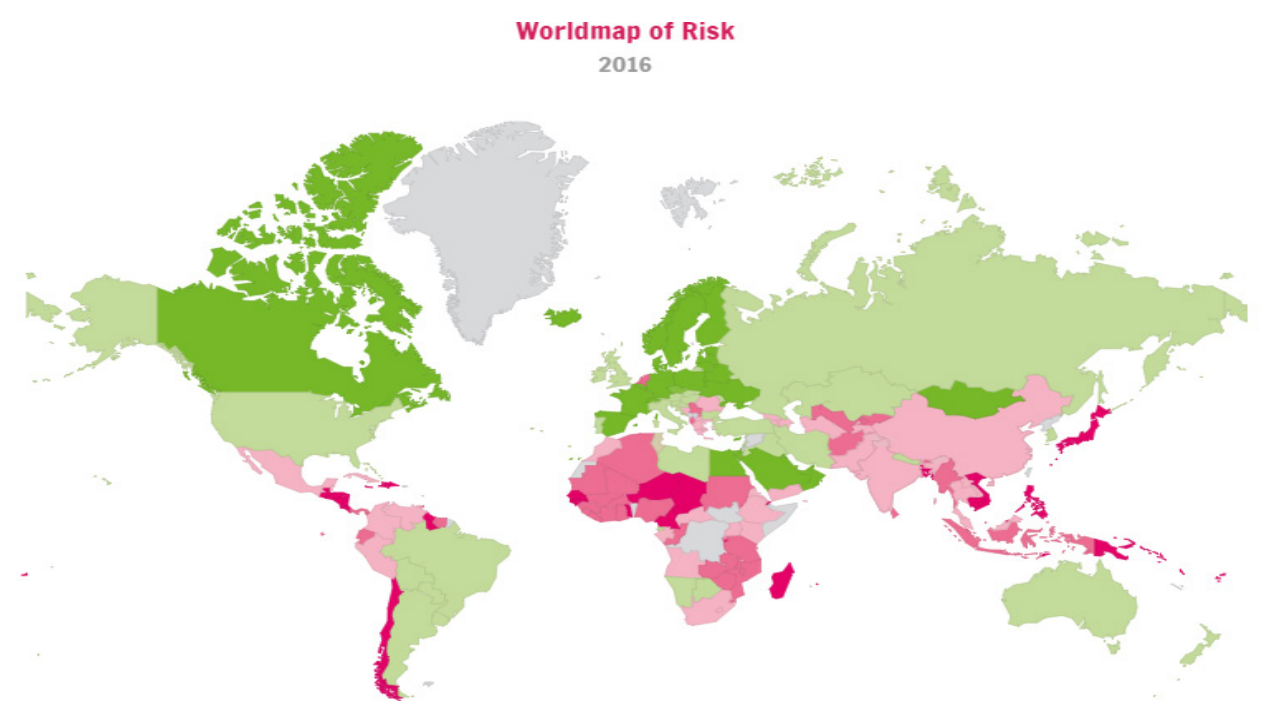

Gambar 1. Peta Dunia Daerah Rawan Bencana Tahun 2016

Sumber: http://weltrisikobericht.de/english/, link diakses pada 16 Agustus 2016. 
Pengalaman membuktikan bahwa bencana alam berimplikasi secara langsung terhadap masyarakat di suatu wilayah. Bukan hanya kerusakan secara fisik, tapi banyak keluarga kehilangan sanak saudara akibat bencana. Kehilangan orang-orang yang dicintai dan rumah yang sudah lama ditinggali merupakan tekanan psikologis bagi warga yang dapat menyebabkan munculnya PSTD (Post Traumatic Stress Disorder atau stres pascabencana (Jia dkk., 2010). Selain itu, dapat muncul pula tekanan psikologis seperti depresi, psikosomatik, dan kecemasan (Wang dalam Chou dkk., 2004). Pada masa pascabencana, individu biasanya menjadi rentan dan tidak berdaya terhadap dampakdampak bencana yang sifatnya traumatis.

Saat bencana terjadi, pemerintah dan masyarakat sering kali lebih fokus pada urusan logistik (sandang, pangan, dan papan) yang diperlukan individu untuk jangka pendek. Sementara perhatian pada level keluarga atau komunitas dan sosial biasanya sering terlupakan, begitu juga perbaikan untuk lembaga-lembaga komunitas/sosial seperti pasar, tempat ibadah, mata pencaharian dan lain-lain. Untuk itulah perlu ada fokus dukungan dari semua level komunitas karena pada saat bencana maupun pascabencana, lembaga-lembaga pada level komunitas tersebut juga mengalami kehancuran.

Dalam perspektif sosiologis, bencana sering kali dipahami berdasarkan persepsi manusia atau masyarakat, dan atas apa yang mereka rasakan terkait pengalaman emosional pada kejadiankejadian yang dapat mengancam kelangsungan hidup mereka. Bencana merupakan salah satu bagian definisi yang disusun dalam suatu konteks sosial budaya hidup masyarakat yang mengalami bencana (Pramono, 2016).

Secara umum, strategi yang digunakan dalam mengelola bencana alam di Indonesia masih bersifat reaktif. Padahal berbagai literatur membuktikan bahwa faktor-faktor yang berhubungan dengan peningkatan kapasitas adaptasi dalam menghadapi bencana merupakan pilihan kebijakan yang wajib diadopsi dan diimplementasikan. Dengan demikian, kesiapsiagaan adalah faktor penting dalam mitigasi bencana. Ada berbagai pendekatan dalam manajemen bencana, di antaranya adalah pendekatan melalui pencegahan. Prinsip utama dalam manajemen bencana adalah kalau tidak mampu mencegah terjadinya bencana, maka wajib mengurangi jumlah korban jiwa.

Pada level keluarga, ke depan kita harus mewujudkan keluarga yang sadar bencana, terutama di wilayah-wilayah rawan. Pada level komunitas, masyarakat perlu membentuk komunitas sadar bencana agar kesadaran serta kemampuan masyarakat dalam menghadapi ancaman bencana dapat ditingkatkan. Masyarakat diharapkan dapat belajar sekaligus berlatih melakukan mitigasi bencana sehingga ketika terjadi bencana masyarakat dapat secara aktif melakukan upaya penyelamatan, bukan hanya pasif menunggu datangnya bantuan atau pertolongan.

Beberapa program memang telah dilakukan pemerintah, di antaranya program Desa Tangguh Bencana (Destana) yang bertujuan untuk memberikan kesiapan khusus serta wawasan mengenai mitigasi bencana sehingga masyarakat siap menghadapi berbagai kemungkinan bencana. Bentuk nyata program ini antara lain pembentukan peraturan desa, perencanaan penanganan bencana tingkat desa, hingga penyusunan anggaran untuk tanggap bencana secara mandiri maupun dengan anggaran desa. Harapannya ke depan masyarakat dapat memahami siklus penanggulangan bencana, yakni pencegahan, mitigasi, rencana siaga, peringatan dini, kesiapsiagaan, kajian darurat, rencana operasional, tanggap darurat, pemulihan, rehabilitasi, dan rekonstruksi. Pada level yang lebih makro, sinergi antara pemerintah, masyarakat, dan dunia usaha dalam implementasi program ini diharapkan akan memberikan kekuatan yang tangguh dalam menerapkan living in harmony with disaster risks.

Sejak 2007, Indonesia sebenarnya telah memiliki Undang-Undang Nomor 24 Tahun 2007 tentang Penanggulangan Bencana. Menurut UU ini, penyelenggaraan penanggulangan bencana meliputi kesiapsiagaan, peringatan dini, dan mitigasi bencana. Terkait dengan mitigasi bencana, sering 
kali masih terkendala dengan persepsi masyarakat yang belum sepenuhnya paham tentang apa dan bagaimana cara menghadapi bencana alam. Harus diakui, memang tidak mudah membentuk cara pandang masyarakat agar menyadari pentingnya tanggap terhadap bencana.

Berdasarkan latar belakang tersebut, maka permasalahan yang dibahas dalam tulisan ini adalah bagaimana kesadaran bencana masyarakat Karo yang terkena bencana erupsi Gunung Sinabung dan masyarakat Banjarnegara yang alami bencana longsor? Pelajaran apa yang bisa kita ambil dari pengalaman Jepang, sebagai negara yang sukses membangun kesadaran bencana bagi warganya?

Tulisan ini bertujuan untuk memberi gambaran tentang kesiapsiagaan, kewaspadaan dan kesadaran masyarakat di lokasi rawan bencana dalam memahami bencana dan upaya yang mereka lakukan dalam rangka mengurangi risiko bencana. Sementara itu, manfaat tulisan ini diharapkan dapat memberi masukan dalam pelaksanaan kebijakan penanggulangan bencana khususnya terkait upaya membangun masyarakat sadar bencana. Manfaat terutama sebenarnya bagi Pemerintah Daerah Kabupaten Karo dan Pemerintah Kabupaten Banjarnegara serta masyarakat di wilayah rawan bencana dalam mengambil keputusan terkait upaya perbaikan dalam membangun kesiapsiagaan, kewaspadaan dan kesadaran masyarakatnya dalam mengantisipasi bencana.

Penelitian ini dilakukan dengan metode pendekatan kualitatif. Pengumpulan data dilakukan dengan cara wawancara mendalam dan observasi partisipasi. Informan adalah pejabat di kantor Badan Penanggulangan Bencana Daerah (BPBD), para pengungsi, dan warga yang sudah melakukan relokasi pascabencana. Data ditentukan berdasarkan kecukupan informasi tentang kewaspadaan dan kesadaran masyarakat mengenai bencana yang sering terjadi di wilayahnya serta peluang terjadinya bencana serupa di kemudian hari. Kecukupan data adalah saat data dianggap sudah jenuh ketika terjadi keberulangan informasi yang didapat dari metode triangulasi data.
Penelitian dilakukan di dua wilayah yaitu di Kabupaten Karo, Sumatera Utara yang mengalami bencana erupsi Gunung Sinabung serta di Kabupaten Banjarnegara, Jawa Tengah yang mengalami bencana tanah longsor. Peneliti juga mengamati secara langsung lokasi-lokasi penampungan pengungsi (tempat tinggal sementara sebelum direlokasi ke rumah pengganti sebagaimana yang telah dijanjikan sebelumnya). Penelitian ini dilakukan selama tujuh bulan dari bulan Juni hingga Desember 2016.

\section{Sadar Bencana dan Pelajaran dari Jepang}

Meski sebagian besar masyarakat tinggal dan mencari penghidupan di tengah wilayah yang berisiko bencana alam, namum umumnya mereka tidak siap menghadapi bencana. Tidak terlihat adanya tradisi sigap menghadapi bencana yang umumnya datang sewaktu-waktu. Tabel 1 menjelaskan beberapa bencana alam besar yang pernah terjadi di Indonesia dengan jumlah korban jiwa yang banyak.

\begin{tabular}{|c|c|c|c|}
\hline Tahun & Jenis Gempa & Lokasi & $\begin{array}{c}\text { Korban } \\
\text { Jiwa }\end{array}$ \\
\hline 2018 & $\begin{array}{l}\text { Gempa dan } \\
\text { Tsunami }\end{array}$ & $\begin{array}{l}\text { Sulawesi } \\
\text { Tengah }\end{array}$ & 2.010 \\
\hline 2018 & Gempa & Lombok & 515 \\
\hline 2009 & Gempa & Sumatera Barat & 1.117 \\
\hline 2006 & Gempa & Yogyakarta & 6.234 \\
\hline 2004 & Tsunami & Aceh & 220.000 \\
\hline 1992 & Tsunami & Flores & 2.100 \\
\hline
\end{tabular}

Hasil survei yang dilakukan Litbang Kompas pada Juli 2011 di daerah-daerah padat penduduk yang tergolong rawan bencana, yakni Kota Banda Aceh, Padang, Bengkulu, Palu, Yogyakarta, dan Karangasem, menunjukkan bahwa mayoritas masyarakat tidak siap menghadapi bencana alam. Bahkan, kesadaran bahwa mereka hidup di daerah rawan bencana alam pun ternyata masih rendah. Hampir separuh dari 806 responden dalam survei tersebut menyatakan bahwa daerah tempat tinggal mereka tidak rawan bencana. Padahal jelas kawasan itu tergolong rawan bahaya bencana. Rendahnya kewaspadaan ini dipengaruhi oleh 
cara pandang sebagian besar masyarakat dalam menilai bencana alam. Masyarakat cenderung pasrah dan menerima apa yang diberikan alam. Masyarakat cenderung melihat bencana alam sebagai takdir yang tidak bisa dihindari.

Clyde Kluckhohn, seorang antropolog berkebangsaan Amerika Serikat dalam karyanya yang berjudul Universal Categories of Culture sebagaimana dikutip Koentjaraningrat (1994: 203-204), telah membagi cara pandang manusia terhadap alam dalam tiga orientasi nilai. Pertama, manusia tunduk kepada alam sehingga hanya bisa pasrah (manusia tradisional). Kedua, manusia berusaha mencari keselarasan dengan alam (transformasi). Ketiga, manusia berhasrat menguasai alam (manusia modern). Selanjutnya Koentjaraningrat, secara spesifik menjelaskan hubungan manusia dengan alam. Masyarakat, khususnya masyarakat Jawa pedesaan, memiliki ikatan yang sangat kuat dengan alam. Masyarakat memilih untuk berusaha hidup selaras dengan alam. Namun, jika berhadapan dengan kekuatan alam yang membawa maut seperti bencana, mereka cenderung menyerah secara total kepada nasib. Mereka tidak berusaha banyak untuk melawan bencana itu atau menyelamatkan diri. Bagi mereka, bencana alam merupakan sesuatu yang harus diterima apa adanya.

Pandangan pasrah terhadap bencana alam tersebut juga terlihat dari respons sebagian responden dalam survei Kompas (2011) tersebut. Karakteristik masyarakat yang cenderung pasrah terlihat begitu dominan, termasuk pada mereka yang memiliki pengalaman menjadi korban bencana alam. Kondisi ini yang membuat mayoritas korban bencana tak khawatir untuk kembali ke daerah tempat tinggal mereka semula. Kondisi ini juga dialami oleh Halimatus Sadiah (46), salah satu responden survei dari Aceh. Ia menjadi salah satu korban bencana tsunami yang melanda Banda Aceh akhir tahun 2004. Meskipun mengalami kehilangan anggota keluarga dan harta benda, namun tidak pernah terlintas dalam pikirannya untuk pindah ke daerah lain. Menurutnya, tinggal di mana pun, jika sudah menjadi kehendak Tuhan, bencana alam akan tetap terjadi.
Kelompokmasyarakat dengankarakter seperti ini tampak dominan dan tersebar merata di semua daerah yang diteliti oleh Kompas. Paradigma berpikir konvensional yang menilai bencana alam adalah hukuman atau bahkan kutukan yang diberikan oleh Tuhan akibat dosa-dosa manusia, masih tertanam kuat di tengah benak masyarakat. Rata-rata tidak lebih dari 10 persen responden yang memiliki kesadaran bahwa risiko bencana dapat dihindari atau diminimalisasi bila mereka memiliki pengetahuan yang luas dan persiapan menghadapinya secara matang.

Tingkat pendidikan dan cara pandang masyarakat sangat dipengaruhi latar belakang pendidikan. Survei Kompas ini menemukan fakta bahwa semakin rendah tingkat pendidikan responden, maka cara pandang mereka terhadap bencana alam juga semakin mirip karakter masyarakat tradisional. Cara pandang tradisional inilah yang mempengaruhi perilaku sehari-hari mereka dalam menghadapi bencana. Mereka yang berpandangan tradisional cenderung tidak melakukan persiapan khusus menghadapi bencana. Meskipun bencana alam kerap terjadi di daerah, tidak banyak masyarakat yang memiliki kesadaran untuk mempersiapkan diri dan keluarga jika bencana alam terjadi lagi. Di lingkungan sosial paling kecil atau lingkup keluarga, sangat sedikit yang melakukan persiapan paling dasar untuk menghadapi bencana.

Demikian pula soal antisipasi dampak bencana mulai dari hal-hal kecil hingga yang besar cenderung tidak dilakukan. Lebih dari 90 persen responden survei Kompas mengaku sama sekali tidak pernah berlatih evakuasi atau mempelajari tindakan pertolongan pertama jika terjadi bencana. Bahkan, tidak kurang dari separuh responden menyatakan tidak pernah membahas atau membicarakan dengan anggota keluarga lainnya terkait tindakan apa yang harus dilakukan jika terjadi bencana alam.

Sebagai contoh pada bencana letusan Gunung Merapi, local coping mechanism terhadap kondisi alam ini, termasuk bencana meletusnya gunung tersebut, telah berlangsung selama bertahun-tahun di kalangan masyarakat Jawa yang berada di sekitarnya (Singgih, 2006: 
254-255). Sindhunata (1998) mendeskripsikan bagaimana penduduk memahami dan berusaha merespon fenomena Gunung Merapi. Dua sisi yang kontradiksi; pada satu sisi, letusan Gunung Merapi dimaknai sebagai ancaman yang dapat mematikan atau menuntut korban manusia, tetapi di sisi lain bencana tersebut memberikan kesuburan dan kehidupan bagi manusia yang tinggal di sekitarnya. Pandangan ini menunjukkan bahwa eksistensi Gunung Merapi dan potensinya diterima dan dihayati dalam perspektif keseimbangan (dual dimensions). Di satu sisi Gunung Merapi dapat mengakibatkan bencana melalui letusan dan "wedus gembel" yang dapat menghancurkan, tetapi di sisi lain, Gunung Merapi menjadi berkah bagi masyarakat yang tinggal di sekitarnya berupa kesuburan tanah, material pasir hasil letusan, objek kegiatan wisata, dan sebagainya.

Terkait dengan sadar bencana pada level masyarakat, ada baiknya jika kita belajar dari masyarakat Jepang. Secara geografis, negara Jepang berada dalam posisi yang rentan terhadap bencana alam. Jepang paling sering mengalami gempa bumi dengan kekuatan rata-rata diatas 6 Skala Richter (SR). Selain gempa, Jepang juga sering mengalami tsunami, badai topan, erupsi gunung berapi, banjir, serta tanah longsor. Namun demikian, Jepang terkenal memiliki manajemen tanggap bencana yang sangat efektif, sehingga selalu cepat dalam penanganan korban. Respon dari Pemerintah Jepang bersama-sama dengan seluruh elemen masyarakat umumnya sangat cepat dalam menangani situasi pascabencana, melakukan pemulihan atas wilayah terdampak bencana, serta mengatasi masalah kesehatan dan kehidupan para korban yang selamat (Tanaka, 2005). Perlu dipahami bahwa manajemen bencana merupakan suatu penataan dan pengelolaan sumber daya serta tanggung jawab dalam penanganan hal-hal terkait aspek keselamatan manusia, baik dalam tahap kesiagaan, respon, maupun pemulihan kembali atas kejadian bencana, dengan tujuan untuk mengurangi dampak negatif yang diakibatkan oleh bencana tersebut.

Oleh karena adanya anggapan bahwa bencana gempa selalu berulang, maka pemerintah dan masyarakat Jepang merancang dan membangun bangunan-bangunan yang tahan gempa. Selain itu, mereka juga melakukan pemeliharaan lingkungan hidup secara konsisten, seperti perlindungan hutan di pesisir samudra (coastal forests atau hutan mangrove) dan perlindungan awal gelombang tsunami (dengan menempatkan batu-batu pemecah ombak di tepian pantai untuk mengurangi dampak tsunami).

Hal yang tak kalah pentingnya, Jepang mengembangkan sistem peringatan dini bencana alam (disaster-early warning system). Ini dimaksudkan agar semua pihak, mulai dari gugus tugas siaga bencana (disaster task force unit) supaya bisa merespon dengan cepat, serta masyarakat yang berpotensi mengalami dampak bencana agar segera mempersiapkan diri untuk berlindung di tempat yang sudah dipersiapkan. Mereka juga mendirikan area perlindungan bagi korban terdampak bencana alam, serta memberikan pelatihan rutin kepada masyarakat sebagai respon cepat atas bencana alam yang bisa datang kapan saja.

Salah satu yang bisa dipelajari pemerintah dan masyarakat dari Jepang adalah mereka mengembangkan secara terus-menerus sistem tanggap darurat bencana agar mampu bekerja lebih efektif. Pada bencana tsunami akibat gempa berkekuatan 8,5 SR pada tanggal 26 Desember 2004 yang terjadi di Aceh, tercatat korban meninggal mencapai 200.000 orang. Bandingkan dengan bencana tsunami akibat gempa berkekuatan 8,9 SR pada tanggal 11 Maret 2011 di Jepang, tercatat hanya sekitar 7.000 orang korban yang meninggal.

Sebagai perbandingan, Jepang juga pernah alami gempa dan tsunami yaitu gempa sebesar 7.9 SR yang lebih dikenal sebagai "The Great Kanto Earthquake" pada tahun 1923 yang menewaskan lebih dari 142.000 orang. Jumlah korban yang berbeda jauh antara bencana gempa dan tsunami di Aceh pada tahun 2004 dan di Jepang pada tahun 2011 menunjukkan bahwa Jepang lebih siap menghadapi bencana dibandingkan dengan Aceh pada saat itu.

Jika dibandingkan dengan negara-negara yang dilanda gempa bumi, Jepang merupakan negara 
yang paling sering mengalami gempa bumi. Hal ini menyebabkan Jepang menjadi negara yang paling siap menghadapi bencana gempa bumi dan tsunami. Berbagai macam cara dilakukan Jepang untuk mengurangi dampak bencana, mulai dari meningkatkan kesadaran masyarakat sejak dini, membangun infrastruktur bangunan yang tahan gempa, membangun jalur evakuasi bagi keselamatan warga, bahkan ada sebuah perusahaan di Jepang yang menciptakan sebuah kapsul penyelamat diri kala tsunami melanda.

Hal penting lainnya agar tercipta masyarakat yang sadar bencana adalah melalui pendidikan menghadapi bencana yang diberikan kepada anak-anak sejak usia dini. Bukan hanya dididik secara fisik dalam evakuasi diri saat bencana, tetapi juga dididik secara mental dan dilatih secara rutin. Sistem pendidikan Jepang yang menyiapkan masyarakat dan anak-anak mereka dalam menghadapi bencana, patut ditiru oleh Indonesia. Sebagai negara yang cukup sering mengalami bencana alam, sudah seharusnya Indonesia memasukkan edukasi bencana masuk dalam kurikulum pendidikan.

Selain pendidikan bencana sejak dini, pelatihan evakuasi tsunami atau lebih dikenal sebagai tsunami drill rutin dilakukan oleh Jepang sejak tanggal 1 September 1995. Tanggal tersebut bertepatan dengan peringatan hari penanggulangan bencana. Sejak tahun 1960, hari penanggulangan bencana Jepang ini diperingati untuk mengenang bencana gempa dan tsunami "The Great Kanto Earthquake." Pada hari peringatan, anak-anak sekolah di Jepang serentak menggelar simulasi evakuasi jika terjadi gempa dan tsunami. Letak sekolah-sekolah di Jepang pun dipilih di lokasi paling aman dan disiapkan menjadi pusat evakuasi bagi komunitas sekitarnya.

Latihan merupakan elemen yang sangat berperan penting untuk membangun kesadaran, kewaspadaan dan kesiapsiagaan dalam menghadapi bencana (Badan Nasional Penanggulangan Bencana, 2017). Belajar dari pengalaman beberapa negara maju yang rawan bencana seperti Jepang, Amerika Serikat, Jerman, Korea Selatan, dan beberapa negara di Eropa, bahwa secara umum kesadaran, kewaspadaan dan kesiapsiagaan mereka telah tumbuh serta berkembang melalui pelatihan secara teratur.

Hasil survei di Jepang pada kejadian gempa Great Hanshin Awaji 1995 menunjukkan bahwa persentase korban selamat disebabkan oleh karena upaya diri sendiri sebesar 35\%, anggota keluarga $31,9 \%$, teman atau tetangga $28,1 \%$, orang lewat 2,60\%, Tim SAR 1,70\%, dan lain-lain $0,90 \%$. Berdasarkan data ini sangat jelas membuktikan bahwa faktor yang paling menentukan dalam menghadapi datangnya bencana adalah penguasaan pengetahuan yang dimiliki "diri sendiri" untuk menyelamatkan dirinya dari ancaman risiko bencana (Badan Nasional Penanggulangan Bencana, 2017:12).

Proses penyadaran tersebut berguna agar setiap orang yang dapat memahami risiko mampu mengolah ancaman dan pada gilirannya berkontribusi dalam mendorong ketangguhan masyarakat dari ancaman bahaya bencana. Di samping itu, kohesi sosial, gotong royong, dan saling percaya merupakan nilai perekat modal sosial yang telah teruji dan terus dipupuk, baik kemampuan perorangan dan masyarakat secara kolektif, untuk mempersiapkan, merespon, dan bangkit dari keterpurukan akibat bencana.

Sebagai proses ketahanan sosial dan budaya sadar bencana dalam jangka panjang, ketangguhan masyarakat (Bene et al, 2012) menyasar tiga elemen ketangguhan, yaitu: kapasitas meredam ancaman (absorptive) yang menghasilkan persistensi, kemampuan beradaptasi (adoptive) yang menghasilkan penyesuaian perlahan dan berjangka panjang, dan kapasitas bertransformasi (transformative) yang menghasilkan responrespon transformasional. Latihan kesiapsiagaan diartikan sebagai bentuk latihan koordinasi, komunikasi, dan evakuasi dengan melibatkan seluruh pemangku kepentingan (pemerintah dan masyarakat) sehingga mampu meningkatkan keterampilan dalam koordinasi serta pelaksanaan operasi penanggulangan bencana.

Selain pendidikan bencana sejak dini dan tsunami drill, Jepang selalu merevisi tata ruang wilayah mereka. Seperti yang terlihat usai gempa dan tsunami tahun 2011, 12 pemerintah 
daerah yang terdampak tsunami meninggikan tanah di wilayah mereka. Rata-rata ditinggikan satu hingga enam meter. Beberapa wilayah bahkan ditinggikan hingga 17 sampai 18 meter. Pemukiman warga pun dibangun kembali pada posisi menjauh dari zona tsunami.

Itulah beberapa bentuk mitigasi bencana Jepang yang bisa diadopsi oleh Indonesia untuk mengurangi dampak dan korban bencana tsunami. Pembelajaran dari pemerintah Jepang bukan hanya soal infrastruktur yang sarat dengan perencanaan matang dan pertimbangan resiko alam. Bahkan, nilai terhadap bencana dan risikonya, telah tertanam di dalam benak masyarakat. Hal inilah yang membuat seluruh elemen masyarakat siap sedia dan terlihat matang dalam menghadapi risiko terburuk sekalipun.

\section{Kasus Bencana Longsor Banjarnegara}

Pada tahun 2014 terjadi bencana longsor di Dusun Jemblung, Desa Sampang, Kecamatan Karangkobar, Kabupaten Banjarnegara, Provinsi Jawa Tengah. Sebagaimana diketahui, Dusun Jemblung merupakan daerah rawan longsor dengan intensitas sedang hingga tinggi. Pada dua hari menjelang terjadinya longsor yaitu tanggal 10 dan 11 Desember 2014, wilayah di sekitar Dusun Jemblung diguyur hujan yang cukup deras. Akibatnya, tanah di lokasi tersebut menjadi penuh air padahal materi penyusun bukit Telaga Lele tempat Dusun Jemblung berada merupakan endapan vulkanik tua sehingga solum atau lapisan tanahnya cukup tebal dan terjadi pelapukan. Selain itu, kemiringan lereng di bukit tersebut juga kurang dari $60 \%$.

Sementara itu, tanaman di atas bukit tempat terjadinya longsor adalah tanaman semusim dengan jenis palawija yang tidak rapat sehingga tanah menjadi longgar dan mudah terbawa air. Diduga penyebab longsor tidak lepas dari ulah manusia sendiri. Budi daya pertanian yang tidak mengindahkan konservasi juga menjadi penyebab longsor. Di lereng lokasi kejadian juga dilakukan terasering.

Bencana longsor sebenarnya bukan hal baru bagi masyarakat di Kecamatan Karangkobar, Banjarnegara. Di kecamatan yang memiliki 13 desa ini hampir setiap tahun selalu terjadi bencana serupa walaupun dalam skala lebih kecil. Penyebabnya adalah karena secara alami kondisi wilayah di Karangkobar memang tidak memungkinkan untuk dijadikan wilayah permukiman. Kondisi topografinya yang berbukit-bukit dan tekstur tanahnya yang tidak kokoh menjadikan daerah ini mudah sekali terkena bencana longsor. Kondisi geologis wilayah ini memang memiliki tanah yang rapuh. Tanahnya disisipi bebatuan dan saat hujan tiba bidang-bidang yang memotong ikatan antara tanah dan batuan rentan longsor.

Terkait dengan penanganan bencana tersebut, peran negara dan masyarakat mutlak diperlukan. Peran negara diwakili oleh keberadaan BNPB dan BPBD yang langsung mengambil tindakan saat bencana terjadi. Sementara itu, partisipasi masyarakat dibutuhkan untuk mengurangi dan menghindari risiko bencana penting dilakukan dengan cara antara lain meningkatkan kesadaran dan kapasitas masyarakat (Suryanti dkk, 2010). Dalam penelitiannya, Zein (2010) menjelaskan bahwa masyarakat merupakan pihak yang memiliki pengalaman langsung dalam kejadian bencana sehingga pemahaman yang dimiliki menjadi modal bagi pengurangan risiko bencana. Dalam konteks manajemen bencana alam, respons masyarakat terhadap bencana sangat penting untuk dipahami (Marfai dkk., 2008).

Respons merupakan awal dari sebuah strategi adaptasi oleh masyarakat yang dihasilkan melalui pemahaman terhadap bencana alam yang terjadi. Pemahaman masyarakat berupa pengetahuan dan persepsi yang teraktualisasi dalam sikap dan/atau tindakan dalam menghadapi bencana. Hasil dari sikap dan/atau tindakan masyarakat dalam menghadapi bencana adalah strategi adaptasi yang berarti penyesuaian yang dilakukan akibat ancaman lingkungan sekitar.

Mengingat pentingnya adaptasi dan ketahanan sosial (social resilience) pada masyarakat yang mengalami bencana, ke depan perlu diperbanyak studi mengenai strategi adaptasi yang dilakukan oleh masyarakat, baik pada tingkat individu maupun kelompok, dalam 
menghadapi bencana. Adaptasi merupakan hasil akhir sikap masyarakat yang muncul berdasarkan persepsi dan pengetahuan mereka terhadap potensi bencana. Faktanya, studi-studi mengenai strategi adaptasi dan ketahanan sosial masih jarang dilakukan di Indonesia.

Hampir 70-75\% wilayah Banjarnegara merupakan kawasan rawan longsor karena terletak di lereng dataran tinggi Dieng. Sedikitnya 12 kecamatan dari 20 kecamatan di Kabupaten Banjarnegara, Jawa Tengah termasuk daerah zona merah atau rawan longsor sebab wilayahnya berbukit-bukit dan tanahnya mudah bergerak. Oleh karena sering terjadinya longsor di Banjarnegara, seharusnya masyarakat sekitar memahami dan mengantisipasi sehingga dapat hidup selaras dengan alam. Hal itu penting karena selama ini konsep mitigasi bencana swadaya pada masyarakat yang tinggal di wilayah rawan bencana masih lemah.

Sampai saat ini, masyarakat umumnya masih mengandalkan inisiatif dan bantuan pemerintah. Akibatnya, risiko jatuh korban saat bencana terjadi belum dapat dikurangi. Sejumlah warga di kawasan rawan bencana longsor yang tinggal di perbukitan Banjarnegara mengaku tidak memiliki wawasan mitigasi bencana dan hanya mengandalkan gejala alam. Umumnya masyarakat yang tinggal di daerah rawan longsor merasa terpaksa tinggal di daerah pegunungan karena wilayah perkotaan sudah padat. Biasanya mereka mengandalkan perekonomian dari bertani sehingga pilihan untuk tinggal di daerah berbukit yang rawan seperti ini menjadi pilihan yang terkesan rasional.

Secara umum, wilayah desa yang rawan longsor berada di bawah bukit besar yang sebagian lerengnya dipenuhi tanaman semusim, seperti kentang, kol, dan beberapa varietas hortikultura lain. Akibatnya saat musim hujan dan kondisi tanah labil tanah longsor akan sangat mudah terpicu. Selama ini warga lebih mengandalkan sosialisasi kebencanaan dari pemerintah. Belum ada gerakan swadaya yang diinisiasi warga untuk memunculkan sikap sadar bencana. Bahkan, perilaku warga di sekitar wilayah rawan bencana sudah tidak sesuai dengan kaidah konservasi.
Contohnya adalah Dusun Jemblung yang longsor pada akhir 2014, dari sekitar 150 keluarga di dusun tersebut, 75\% di antaranya memiliki kolam ikan di sekitar rumah. Padahal kolam-kolam ikan tersebut rentan memicu longsor karena akan membuat tanah menjadi lembek.

Langkah pertama yang harus dilakukan pemerintah dan masyarakat adalah pengenalan karakteristik Dusun Jemblung dan sekitarnya, misalnya mengenai bentuk lahan yang berbentuk perbukitan dengan kemiringan sedang hingga terjal, batuan vulkanik, bentuk lereng yang bervariasi, jenis tanah, kondisi curah hujan, dan intensitas sungai di dusun.

Konsep pemahaman mengenai antisipasi bahaya longsor sudah selayaknya diketahui seluruh masyarakat, sehingga diharapkan masyarakat akan mampu mengatasi kondisi di daerahnya. Pemerintah pusat dan pemerintah daerah seharusnya fokus pada upaya penyadaran masyarakat Banjarnegara bahwa mereka hidup di wilayah yang rawan bencana. Mereka harus diedukasi mengenai mitigasi bencana secara baik.

Seperti halnya di wilayah Dusun Jemblung, penanganan yang paling tepat adalah sistem bio-engineering atau teknik tanaman, karena wilayahnya luas dan berbukit-bukit sehingga teknik hard protection seperti membuat "taludtalud" di tepi lereng kurang memungkinkan dan tidak banyak membantu. Cara bio-engineering ini adalah penanganan longsor dengan memperhatikan keseimbangan lereng yang dibentuk oleh tanaman.

Seperti halnya di Bukit Telaga Lele (lokasi di mana Dusun Jemblung berada) dan sekitarnya, pengaturan tanaman sebaiknya memperhatikan sudut kelerengan dan posisi lerengnya. Untuk tanaman palawija dapat ditanam pada lereng bagian bawah dan sudut kelerengan tidak terjal, tapi mesti ada tanaman yang menopang/ memperkuat lereng seperti kaliandra dan tanaman lainnya yang mempunyai perakaran kuat, walaupun jumlahnya tidak banyak. Kemudian makin ke atas, dengan sudut kelerengan makin tinggi masih diperbolehkan menanam tanaman palawija, tapi konsekuensinya tanaman penopang lereng harus diperbanyak karena kondisi lereng 
yang cukup terjal berpotensi terhadap longsor.

Selanjutnya pada lereng-lereng yang sangat terjal bisa jadi hanya tanaman-tanaman penguat lereng yang diperbolehkan. Tanaman-tanaman keras juga dapat berfungsi sebagai penyerap air sehingga mengurangi konsentrasi air di dalam tanah yang secara alami dapat mencegah longsor. Tetapi yang paling penting tanaman ini merupakan tanaman penyangga tanah di daerah lereng yang akan berfungsi mempertahankan tanah dari longsor. Hal ini harus benar-benar dipahami oleh masyarakat sekitar lokasi daerah rawan longsor. Kegiatan nonstruktural seperti sosialisasi pencegahan longsor menjadi agenda penting dalam penanganan longsor dan harus segera dilakukan. Pemerintah sudah seharusnya menggandeng semua elemen masyarakat untuk kegiatan ini, misalnya dengan melibatkan perguruan tinggi, LSM, dan organisasi masyarakat dalam masyarakat sehingga frekuensi longsor dapat ditekan dan masyarakat mampu mencegah longsor.

Bencana longsor sebenarnya bukan hal baru bagi masyarakat di Kecamatan Karangkobar, Banjarnegara, Jawa Tengah. Hampir setiap tahun selalu terjadi bencana serupa di kecamatan yang memiliki 13 desa tersebut. Nyaris setiap tahun juga bencana longsor selalu menelan korban jiwa, harta, dan benda penduduk yang bermukim di wilayah ini. Secara alami, kondisi wilayah di Kecamatan Karangkobar, lokasi Dusun Jemblung, memang tak memungkinkan untuk dijadikan permukiman. Kondisi topografinya yang berbukit-bukit dan tekstur tanahnya yang tak kokoh menjadikan daerah ini mudah sekali mengalami bencana longsor. Secara umum, kondisi geologis wilayah ini memiliki tanah yang rapuh. Tanahnya disisipi bebatuan dan ada bidang-bidang yang memotong ikatan antara tanah dan batuan. Bila hujan tiba, lapisan tanahnya pasti rentan meluncur atau longsor.

Penyebab lain yang juga tak kalah penting adalah sistem pemanfaatan lahan yang tidak tepat oleh masyarakat. Selama hampir 10 tahun ini lereng bukit yang sebelumnya mayoritas ditumbuhi pepohonan dan tanaman keras diganti dengantanamansalak(Salaccazalacca). Tanaman berbatang duri yang dikembangkan secara monokultur oleh warga ini memiliki kekurangan karena tak memiliki tekstur pengakaran yang kuat di tanah. Serabut akarnya yang pendek (kurang dari satu meter) tidak masuk jauh ke dalam tanah sehingga membuat tekstur lapisan tanah menjadi tidak kokoh. Serabut akar pohon salak pendek di tanah dan justru memicu tanah semakin gembur serta rapuh. Karena itu, banyaknya pohon salak yang ditanam warga di Karangkobar menjadi salah satu faktor yang membuat pemicu tanah di wilayah tersebut mudah bergerak. Oleh sebab itu, alternatif kebijakan yang dapat dilakukan adalah penataan kembali kawasan permukiman di daerah itu. Area yang sudah ditetapkan sebagai kawasan terlarang untuk permukiman hendaknya benarbenar dapat ditegakkan sehingga tidak menjadi bencana di kemudian hari. Secara alami wilayah Karangkobar memang rentan, tapi belum tentu berpotensi bahaya. Namun bahaya dapat muncul dengan mudah, baik melalui turunnya hujan atau pemanfaatan lahan yang salah. Jadi, tata ruang di wilayah ini perlu segera dievaluasi.

Berdasarkan pengamatan penulis di lapangan, sebenarnya sudah banyak masyarakat di Kecamatan Karangkobar yang mengetahui bahwa tanah tempat mereka tinggal rawan longsor. Namun dengan berbagai alasan, umumnya karena latar belakang sosial ekonomi, mereka nekat tetap tinggal di wilayah tersebut. Oleh karena itu, bagi Pemerintah Kabupaten Banjarnegara hal yang perlu diprioritaskan adalah persoalan tata guna lahan di wilayah yang memang rawan bencana tersebut. Tata guna lahan yang relatif tidak terkendali berpotensi menimbulkan longsor pada masa kini maupun masa yang akan datang.

Salah satu hal yang perlu mendapatkan perhatian kita ke depan adalah manajemen sumbangan bagi pengungsi. Selama ini, penyumbang rata-rata menginginkan sumbangan diberikan langsung kepada korban atau keluarga korban. Akibatnya sumbangan jadi menumpuk. Jika korban dapat mengelola dana bantuan dengan baik, dana itu dapat dipergunakan sebaik mungkin pada pascabencana. Sebaliknya, jika masyarakat korban tidak dapat mengelola dana bantuan dengan baik, maka dana bantuan 
tersebut cepat habis dan tidak tersisa. Menurut Musobihin, relawan pengelola sumbangan, saat bencana longsor terjadi di Banjarnegara ada aliran dana bantuan yang sangat besar. Lembaga yang ia dirikan mengelola sumbangan hampir Rp 2 miliar. Belum lagi lembaga-lembaga penerima sumbangan lain yang sudah ada sebelum longsor terjadi. Di sinilah upaya transparansi aliran dana harus diutamakan. Pengungsi ataupun masyarakat yang direlokasi merupakan bagian yang harus diutamakan agar mereka bisa bertahan setelah bencana menimpa mereka.

Relokasi adalah upaya pemindahan sebagian atau seluruh aktivitas, berikut sarana dan prasarana penunjang aktivitas, dari satu tempat ke tempat lain guna mempertinggi faktor keamanan, kelayakan, dan legalitas pemanfaatan dengan tetap memperhatikan keterkaitan antara yang dipindah dengan lingkungan alami dan binaan di tempat tujuan. Daerah tujuan relokasi untuk para pengungsi di Banjarnegara hanya berbeda desa. Letak desa relokasi hanya bersebelahan sehingga tidak sepenuhnya mencabut akar sosial budaya pada wilayah sebelumnya. Tanah relokasi juga bersifat hak milik. Ini berbeda dengan pengungsi Sinabung yang status tanahnya masih pinjam pakai.

Dengan lokasi relokasi yang hanya beda desa, secara kultural akar budaya pengungsi Banjarnegara belum sepenuhnya tercabut. Mereka masih mudah mengakses lokasi rumah mereka yang hancur, walaupun dilarang untuk memanfaatkannya karena wilayah tersebut sudah dinyatakan sebagai "wilayah merah atau tidak boleh dimanfaatkan lagi." Perbedaan lain dengan pengungsi Sinabung adalah akses lokasi relokasi dengan jalan raya yang hanya berjarak kurang dari 200 meter sehingga memudahkan mereka untuk melakukan mobilitas secara ekonomi. Karena lokasinya tidak terisolir, mereka dengan mudah mendapatkan pekerjaan serabutan (kuli harian) sehingga dapat bertahan dan meneruskan kehidupan dengan lebih mudah.

\section{Kasus Erupsi Gunung Sinabung Karo}

Gunung Sinabung yang terletak di Kabupaten Tanah Karo Provinsi Sumatra Utara adalah salah satu dari 30 gunung api yang berada di atas Sesar Besar Sumatra. Gunung Sinabung mulai aktif kembali setelah gempa bumi disertai tsunami dahsyat yang mengguncang Aceh pada tanggal 26 Desember 2004, disusul kemudian dengan gempa Nias Maret 2005 dan Juli 2006, lalu gempa di Padang pada Maret 2007 yang berulang pada September 2009 yang diikuti gempa di Pulau Nias lagi pada Oktober 2009. Satu tahun kemudian, 29 Agustus 2010, Gunung Sinabung meletus untuk pertama kali setelah 400-an tahun diam.

Untuk erupsi kali ini, kondisi Gunung Sinabung mengalami peningkatan aktivitas yang signifikan. Pada 15 September 2013, peningkatan status Sinabung diawali dari Level II (waspada), kemudian masuk Level III (siaga) dan mulai 3 November 2013 hingga saat ini statusnya masuk ke level tertinggi yaitu Level IV (awas). Selama periode Desember 2013 sampai Januari 2014 telah terjadi 365 kali erupsi yang memuntahkan awan panas di Gunung Sinabung. Meskipun pada bulan Mei 2014 pemerintah menurunkan status Gunung Sinabung dari awas menjadi siaga, Gunung Sinabung masih menjadi ancaman utama bagi warga Kabupaten Karo.

Erupsi Gunung Sinabung telah menyebabkan sekitar 33.192 jiwa dan 10.322 kepala keluarga mengungsi ke tempat tujuan pengungsi yang tersebar di 37 titik. Kejadian tersebut juga merenggut 17 nyawa di mana 14 di antaranya ditemukan di lokasi dalam radius $3 \mathrm{~km}$ di wilayah Desa Sukameriah, sedangkan 3 orang lainnya yang sebelumnya mengalami luka bakar kemudian meninggal di rumah sakit. Intensitas erupsi yang tinggi juga menyebabkan beberapa desa yang berada di radius $5 \mathrm{~km}$ terpaksa harus direlokasi, mengingat desa-desa tersebut tidak mungkin lagi dihuni.

Kerugian dan kerusakan akibat erupsi Gunung Sinabung yang paling parah adalah di sektor infrastruktur dan pertanian. Meskipun saat ini tanggap darurat masih diberlakukan oleh pemerintah kabupaten Karo terkait dengan erupsi Sinabung, pemerintah sudah mulai mengambil sikap untuk melakukan penanganan-penanganan terkait dengan pemulihan bagi warga terdampak yang telah dinyatakan diizinkan pulang. 
Dana sekitar 28 miliar telah digulirkan oleh BNPB melalui BPBD Kabupaten Karo yang dicanangkan akan digunakan untuk segera mengatasi kebutuhan-kebutuhan warga dalamupaya pemulihan, mulai dari hunian, pangan, pertanian, dan sebagainya. Di samping itu, pemerintah melalui BPBD Kabupaten Karo telah mulai memberikan bantuan kepada warga terdampak. Bantuanbantuan tersebut merupakan bantuan pemulihan yang diarahkan secara khusus kepada desa-desa yang terdampak seperti Desa Sukameriah, Desa Guru Kinayan, Desa Selandi, Desa Bekerah, Desa Berastepu, Desa Kebayaken, Desa Simacem, Desa Kuta Tonggal, Desa Kuta Rayat, Desa Gamber, Desa Sigarang-garang, Desa Suka Nalu, Desa Kuta Gugung, Desa Desa Mardinding, Desa Kuta Tengah, dan Desa Perbaji.

Desa Siosar, Kecamatan Merek, Tanah Karo, Sumatera Utara ditetapkan sebagai tempat relokasi warga korban erupsi Gunung Sinabung. Pembangunan rumah relokasi ini hampir rampung dan sebagian warga malah sudah menerima kunci dan menempati rumah. Kediaman yang masing-masing memiliki luas tanah $100 \mathrm{~m}^{2}$ itu telah dilengkapi fasilitas air bersih, listrik, dan perabotan rumah tangga. Sebagian besar warga enggan menempati rumah relokasi karena belum tersedianya lahan atau ladang yang dijanjikan pemerintah untuk diolah. Sebagaimana diketahui, di tempat tinggal lama, rata-rata mata pencaharian mereka adalah sebagai petani.

Pada tahap pertama pemerintah membangun 370 rumah yang ditempati warga dari desa yang paling parah terkena dampak erupsi Gunung Sinabung yaitu Bekerah, Suka Meriah, dan Simacem. Lahan seluas 458 hektar telah disiapkan untuk menampung total 2.053 jiwa bagi warga korban erupsi Gunung Sinabung termasuk areal pertanian, dengan anggaran pembangunan 1 unit rumah sebesar Rp 59,4 juta.

Meski demikian, realisasi program tersebut di tingkat lapangan masih mengalami kendala, dan tentunya masih memiliki kesenjangan yang cukup luas dalam pemenuhan kebutuhan dasar karena alokasi yang ada dinilai masih sangat minim dan belum mampu memenuhi kebutuhan seluruh warga terdampak.
Berdasarkan hasil wawancara dengan pihak BPBD Kabupaten Karo, ditemukan bahwa pascaerupsi banyak hunian warga yang rusak akibat timbunan material vulkanik. Bagian utama yang paling banyak mengalami kerusakan adalah atap rumah. Di mulai bulan Mei hingga Juni 2014, BPBD Kabupaten Karo telah bekerja sama dengan warga untuk melakukan perbaikan rumah, terutama pada bagian atap, sehingga warga dari 9 desa yang telah dinyatakan boleh kembali ke desa, akan bisa kembali ke rumah masing-masing pada bulan Juli 2014. Inisiasi ini dilakukan untuk memastikan warga mendapatkan hunian yang layak dan tidak lagi harus berada di pengungsian. Meskipun demikian, sebagian warga masih berada di pengungsian, menunggu rumah mereka selesai diperbaiki. BPBD telah merealisasikan bantuan atap rumah sebanyak $43 \%$ atau sekitar 100.000 lembar dari 230.000 lembar seng yang dibutuhkan. Sisa 130.000 seng tersebut telah diakomodir melalui APBD 2014-2015 yang akan direalisasikan pada awal September 2014.

Sebelumnya pemerintah telah mengeluarkan dana sebesar 13 miliar untuk kebutuhan pemulihan pertanian bagi warga 16 desa yang telah dipulangkan pada tahap pertama. Bantuan dana ini diperoleh dari BNPB. Menurut Dinas Pertanian, dana tersebut dibelanjakan untuk pembelian bibit tanaman cepat panen antara lain cabe, tomat, sayuran, dan lain-lain. Selanjutnya untuk warga sembilan desa yang baru saja dipulangkan, belum ada alokasi khusus untuk pemulihan pertanian. Ketersediaan dana yang ada baru akan dialokasikan untuk penanganan warga terdampak yang masih di pengungsian, mengingat Pemerintah Kabupaten Karo masih menyatakan situasi tanggap darurat dan sebagian penanganan masih difokuskan pada tahap tersebut.

Hingga saat ini, seluruh warga terdampak yang sudah diizinkan kembali ke permukiman mereka belum mendapatkan bantuan untuk pemulihan mata pencaharian dari Pemerintah Kabupaten Karo. Di beberapa desa, seperti Desa Mardinding dan Desa Perbaji, banyak warga yang telah berutang untuk memenuhi kebutuhan dasar mereka. Sejak mengungsi hingga saat ini pendapatan yang mereka peroleh hanya dari 
jaminan hidup (khususnya pada masa tanggap darurat lalu) yang telah diberikan oleh pemerintah yang jumlahnya sangat terbatas. Kepala Desa Perbaji, Bapak Martin Ginting, mengutarakan sudah banyak masyarakat yang menjual aset misalnya emas serta berutang demi memenuhi kebutuhan hidup sehari-hari seperti untuk keperluan sekolah anak, makan, dan kebutuhan lainnya.

Sebagian masyarakat berinisiatif untuk bekerja di lahan pertanian orang lain, sayangnya masyarakat setempat tidak membutuhkan tenaga kerja. Sebagian lagi menyewa lahan orang lain dengan harga Rp 6 juta/0,5 hektar/tahun. Namun lahan yang telah digarap hingga saat ini belum ditanami karena keterbatasan modal untuk membeli bibit dan pupuk. Janji pemerintah untuk memberikan bantuan bibit tidak kunjung datang. Berdasarkan hasil wawancara dan diskusi yang dilakukan bersama masyarakat, terungkap bahwa mayoritas masyarakat di sembilan desa tersebut tidak memiliki kemampuan apa-apa kecuali bertani. Mengingat pekerjaan ini mereka lakukan secara turun-menurun, sangat sulit bagi mereka untuk beradaptasi ke kegiatan ekonomi lainnya.

Dari hasil wawancara dengan kelompok masyarakat yang memiliki pekerjaan bertani, mereka berharap pemerintah memberikan bantuan berupa bibit tanaman dengan masa panen yang tidak terlalu lama (sekitar 3-4 bulan) dan memiliki nilai ekonomi yang cukup baik. Harapannya dengan bantuan ini mereka bisa bergerak maju untuk memperbaiki kondisi ekonomi mereka sendiri. Data membuktikan bahwa mata pencaharian para pengungsi Sinabung adalah petani sayur-mayur dan hortikultura. Dengan menjadi petani mereka bisa bertahan hidup dan meneruskan kehidupan pascabencana di wilayah mereka.

Seperti penjelasan di atas, warga terdampak erupsi Gunung Sinabung telah mengalami kerusakan pada sektor mata pencaharian utama mereka yaitu bertani selama hampir satu tahun. Singkatnya, sistem nafkah warga di desa-desa terdampak mengalami kehancuran. Hal ini menyebabkan ekonomi masyarakat menjadi terguncang dan sulit bagi mereka untuk bisa memenuhi kebutuhan dasar saat kembali ke rumah. Tidak sedikit juga masyarakat yang sudah memiliki hutang untuk memenuhi kebutuhan dasar mereka. Di samping itu, warga juga tidak memiliki keahlian lain sehingga kehidupan mereka mayoritas bergantung terhadap hasil pertanian. Memasuki masa transisi pemulihan, khususnya bagi warga sembilan desa yang telah diperbolehkan pulang, dibutuhkan respons cepat untuk memperbaiki kembali kondisi ekonomi mereka.

Program-program jangka pendek yang bersifat memberikan stimulus pendapatan untuk memulai kehidupan para pengungsi di daerah relokasi seharusnya didahulukan. Model penyediaan financial resources melalui Cash for Work (CFW) adalah salah satu cara yang direkomendasikan dalam pemulihan warga terdampak erupsi Sinabung. Program CFW bisa diarahkan untuk memperbaiki atau membangun kembali fasilitas-fasilitas umum yang rusak akibat erupsi Sinabung. Dengan cara ini masyarakat berpeluang melanjutkan dan mengembangkan kembali kehidupan mereka menuju situasi normal. Contoh nyata yang bisa dilakukan adalah melibatkan warga relokasi dalam proyek-proyek padat karya dari pemerintah sehingga mereka bisa melupakan penderitaan pascabencana sekaligus menikmati penghasilan yang layak di saat krisis terberat menimpa mereka.

Berdasarkan fakta di lapangan, pola penanganan pengungsi Gunung Sinabung tampaknya meniru model rehabilitasi dan rekonstruksi masyarakat dan permukiman berbasis komunitas. Model ini berhasil diterapkan untuk merelokasi pengungsi bencana di erupsi Gunung Merapi yang terjadi beberapa tahun lalu. Sayangnya, dibandingkan dengan pengungsi Merapi, pemulihan nasib pengungsi Gunung Sinabung berjalan lebih lambat. Faktor yang membuatketahanan mereka menjadi rentan adalah terlalu lamanya para pengungsi menganggur dan menunggu serta terlalu bergantung pada bantuan dari pemerintah. Pemerintah daerah terlalu fokus pada upaya membangun lokasi perumahan relokasi sementara upaya untuk mendorong para korban agar bisa mendapatkan kembali mata pencaharian dan pendapatan keluarga justru 
terabaikan. Bahkan ketika peneliti mewawancarai Bapak Ginting, pengungsi yang telah menghuni rumah relokasi, masih ada keluhan ketiadaan pendapatan dan pekerjaan. Sebagai petani sayurmayur, Bapak Ginting sebenarnya lebih memilih diberi lahan pertanian dari pada dibangunkan rumah oleh pemerintah. Dengan lahan pertanian, ia bisa bekerja dan menghasilkan uang. Mengenai rumah, para pengungsi mengaku sebenarnya mereka terbiasa tidur di ladang pertanian dengan cara membangun gubuk-gubuk sederhana. Dengan bertani ia bisa mempunyai penghasilan, dan setelah berpenghasilan ia pun bisa membuat rumah yang permanen nantinya.

Dari keluhan-keluhan para pengungsi ini seharusnya pemerintah, baik pusat maupun daerah, mendahulukan dan memprioritaskan faktor ketahanan pengungsi dari sisi mata pencaharian terlebih dahulu. Tanpa bantuan untuk mendukung mereka menjadi mandiri secara ekonomi, keadaan mereka sebenarnya rentan secara psikologis maupun sosiologis. Saat ini faktor yang membuat para pengungsi bisa bertahan hidup sepenuhnya adalah bantuan dari saudara dan tetangga terdekat.

Di tengah situasi yang tidak berpenghasilan tetap, namun tetap bertahan inilah yang membuat para pengungsi Sinabung mempunyai resiliensi (daya lenting) yang luar biasa. Bahkan lokasi perumahan mereka yang jauh dari desa terdekat sekitar 7 hingga 8 kilometer membuat mereka terisolir secara ekonomi. Biaya hidup menjadi demikian mahal karena faktor transportasi.

Saat ini, untuk menopang hidup mereka hanya mengandalkan kerja serabutan. Para pengungsi yang tinggal di lokasi relokasi sepenuhnya bertahan hidup dari dukungan keluarga terdekat. Memang ada beberapa rumah yang sudah memulai kegiatan ekonomi skala kecil seperti membuka warung kelontong ataupun berjualan bensin eceran (dua hal yang sangat diperlukan warga di lokasi yang jauh dari keramaian).

Hal lain yang membuat warga yang direlokasi selalu waspada adalah soal status tanah yang mereka tempati. Status tanah tersebut masih bersifat pinjam pakai. Seharusnya pemerintah membeli lahan lain yang bukan kawasan hutan, bukannya malah menempatkan masyarakat di kawasan hutan. Karena hak masyarakat pengungsi Sinabung hanyalah pinjam pakai untuk jangka waktu tertentu, bagaimana nasib para pengungsi setelah jangka waktunya pinjam pakainya habis? Ini yang dikhawatirkan akan memicu konflik tanah di masa depan.

Dari sisi aturan hukum, menurut Jimmy Panjaitan (Sekretaris Jenderal Komunitas Peduli Hutan Sumatera Utara/KPHSU), pemerintah diduga menabrak aturan tentang pinjam kawasan hutan. Berdasarkan Peraturan Menteri Kehutanan Nomor P.16/Menhut/II/2014 tentang Pedoman Pinjam Pakai Kawasan Hutan Pasal 9 Ayat 2, luas kawasan pinjam pakai untuk pembangunan fasilitas umum non-komersial paling banyak lima hektar. Begitu juga dengan isi dari Peraturan Direktur Jenderal Planologi Kehutanan Nomor P.14/VII/PKH/2012 Pasal 2 ayat 1 tentang Petunjuk Pelaksanaan Pinjam Pakai Kawasan Hutan yang dilimpahkan dari Menteri Kehutanan ke Gubernur, disebutkan bahwa izin pinjam pakai kawasan hutan hanya untuk penampungan sementara, jika terkait bencana dan luasnya tidak lebih dari 5 hektar. Sebagaimana diketahui, hutan yang berada di Desa Siosar tempat relokasi tersebut masih berstatus kawasan lindung.

Terkait dengan ketahanan keluarga, kasus di Kabupaten Tanah Karo menunjukkan adanya pola asuh orang tua yang longgar karena orang tua memilih sibuk berladang dan berkebun. Sebagaimana diketahui, pola berladang dan berkebun masyarakat Karo dengan adalah berangkat pagi hari dan pulang malam hari sehingga anak-anak usia SD, SMP, dan SMU tidak menerima pengawasan yang berarti setelah jam belajar di sekolah. Akibatnya anak-anak seakan terlepas dari pengawasan orang tuanya. Akibat lain adalah fenomena kenakalan remaja di Tanah Karo yang meningkat. Hal ini diakui sendiri oleh Sekretaris Daerah Kabupaten Tanah Karo, Ibu Saberina Tarigan. Ia malah menganjurkan pendidikan sekolah diadakan sampai sore hari sehingga anak-anak masih tetap dalam pengawasan guru daripada dibiarkan bebas di rumah tanpa pengawasan orang tuanya yang sibuk berladang. 


\section{Kurang Antisipasi}

Mencermati dua kasus bencana di atas yaitu longsor di Banjarnegara dan erupsi Gunung Sinabung, kemungkinan datangnya bencana alam di kedua wilayah tersebut harusnya dapat diantisipasi sebelumnya. Selama 25 tahun terakhir, lebih dari 20 kebijakan penanggulangan bencana alam sebenarnya telah dibuat pemerintah. Semua kebijakan tersebut memiliki substansi yang sama, yakni berupaya melindungi masyarakat dari dampak bencana. Namun, sejauh ini pemerintah belum terbukti secara nyata mampu menggerakkan masyarakat untuk lebih siap dalam menghadapi bencana. Hal ini terlihat dari fasilitas fisik atau program antisipasi bencana yang masih begitu minim. Ketersediaan sarana peringatan dini dan jalur evakuasi dianggap belum memadai. Infrastruktur mitigasi umumnya hanya tersedia di daerah yang baru saja dilanda bencana alam. Setelah itu perawatannya seringkali terabaikan.

Hasil survei Litbang Kompas (2011) misalnya, mendapatkan fakta bahwa separuh responden di daerah-daerah yang terkena tsunami di Aceh mengaku tidak adanya sarana evakuasi yang layak di daerah mereka. Sementara 20 persen responden lainnya di daerah itu mengaku tidak tahu soal keberadaan jalur evakuasi di daerah mereka. Padahal mitigasi risiko yang timbul dari bencana alam serta adaptasi pascabencana menjadi hal yang krusial dipahami dan dilakukan oleh masyarakat. Peran pemerintah dalam sosialisasi sangat besar. Program ini pun ternyata masih belum optimal.

Masih menurut survei tersebut, mayoritas responden (85 persen) merasa tidak pernah dilibatkan dalam berbagai program kegiatan penanggulangan bencana. Fakta ini semakin menguatkan, budaya sadar bencana di negeri yang sarat ancaman bencana alam ternyata masih tipis.

Perilaku tersebut kemudian nampaklah pada penanggulangan risiko bencana di mana masyarakat yang berkawan dengan alam sudah bersiap-siaga dan antisipatif terhadap bencana. Bencana bagi masyarakat yang sudah tercerahkan akan dijadikan isu rutinitas dalam kehidupan sehari-hari sehingga tidaklah kaget apabila terjadi bencana karena sudah diprediksi sebelumnya dan direncanakan manajemen bencananya.

Bagi masyarakat yang belum menjadikan perencanaan penanggulangan bencana sebagai isu publik, umumnya akan terlihat sangat fatalistik di mana hanya pasrah ketika bencana itu datang sambil berharap bantuan orang lain. Pada akhirnya pola tersebut menurun pada rezim pengaturan bencana yang menempatkan negara sebagai aktor dominan dalam penanganan bencana. Negara yang mengikuti prinsip fatalis akan menerapkan prinsip minimalis atau sekedar memenuhi kewajiban dalam melakukan upaya tanggap darurat. Hal ini berbeda dengan negara yang serius dalam mempersiapkan terjadinya bencana. Begitupun juga dalam dalam bencana, namun kurang dalam kebersamaan dan negara egalitarian yang deliberatif dalam bencana serta menjunjung tinggi kebersamaan dalam menghadapi bencana sebagai masalah bersama (commons problem).

\section{Penutup \\ Simpulan}

Berdasarkan penelitian penulis, persepsi yang berkembang di kalangan masyarakat korban bencana Gunung Sinabung dan longsor Dusun Jemblung Kabupaten Banjarnegara adalah bahwa bencana dianggap sebagai bentuk ujian dari Tuhan sehingga harus diterima apa adanya. Sikap pasrah menerima keadaan ini ternyata menjadi sumber kekuatan individu sehingga pada umumnya mereka sudah bisa melupakan peristiwa bencana tersebut tanpa mengalami stres berkepanjangan. Kesadaran untuk menerima musibah juga menjadi jalan pembuka bagi pemerintah agar lebih mudah menjalankan kebijakan penanggulangan bencana tanpa resistensi masyarakat korban.

Hampir semua pengungsi dan korban bencana di kedua daerah sebenarnya memahami sepenuhnya bahwa lokasi yang dulu mereka huni adalah daerah rawan bencana alam dalam kategori sedang hingga tinggi. Itulah sebabnya upaya relokasi oleh pemerintah pusat dan pemerintah daerah minim resistensi. Relokasi dianggap sebagai pilihan terbaik agar mereka dapat bertahan dan meneruskan kehidupan. 
Pada masyarakat Banjarnegara, kesadaran bahwa mereka bertempat tinggal di lokasi rawan bencana sepenuhnya sangat mereka pahami. Hanya karena faktor ekonomi mereka terpaksa tetap tinggal di wilayah berbahaya tersebut. Hal ini berbeda dengan masyarakat Sinabung, di mana hampir 400 tahun Sinabung "diam" dan "tidak beraktivitas" sehingga kesadaran akan bahaya erupsi belum dipahami sepenuhnya oleh masyarakat. Respons masyarakat Sinabung terhadap bencana tersebut pun terkesan mendadak.

Fakta di lapangan membuktikan bahwa pemerintah pusat, pemerintah daerah, dan masyarakat sering kali lebih fokus pada bantuanbantuan logistik yang diperlukan individu dan bersifat jangka pendek seperti sandang, pangan, dan papan. Namun pada level komunitas atau sosial, rehabilitasi dan perbaikan lembagalembaga komunitas/sosial seperti pasar, tempat ibadah, sekolah, mata pencaharian, dan lainlain pada kasus relokasi pengungsi Gunung Sinabung sangat terlupakan. Ke depannya, BPBD dan BNPB, serta semua pihak juga harus memfokuskan pada perbaikan lembaga-lembaga level komunitas yang ikut hancur pada waktu terjadi bencana dan yang tak kalah pentingnya adalah membangun kesadaran warga di benak seluruh warga masyarakat.

Dengan mengambil pelajaran dari cara Jepang membangun kesadaran warga dalam mempersiapkan terjadinya bencana, maka selayaknya masyarakat dibiasakan ikut di dalam pelatihan evakuasi bencana. Harapannya saat bencana benar-benar terjadi, maka warga tidak lagi panik dan nantinya dengan tenang mereka mengikuti prosedur standar yang telah berkalikali mereka ikuti. Demikian halnya dengan sistem peringatan dini terhadap bencana gempa dan tsunami berjalan dengan baik dan hasilnya dengan cepat terdistribusi kepada masyarakat. Hasil akhirnya adalah kesadaran bencana di kalangan warga Jepang terlihat dengan jelas dari sikap mereka yang mementingkan keselamatan umum.

Dari Jepang kita juga belajar soal penataan dan pengelolaan sumber daya serta tanggung jawab dalam penanganan hal-hal terkait aspek keselamatan manusia, baik dalam fase kesiagaan, respon, maupun pemulihan kembali atas kejadian bencana. Mitigasi bencana terbaik selalu mencakup tiga hal, seperti dilakukan di Jepang, antisipasi bencana alam, penanganan bencana alam dan pemulihan pascabencana. Ketiganya integratif dan komprehensif di dalam setiap kebijakan yang diambil pemerintah. Ketiga hal itu patut kita tiru di Indonesia, sebagai salah satu negara rawan bencana. Pemerintah kita harus memprioritaskan kesadaran bencana di masyarakat dampak dan korban bencana dapat diminimalisasi.

\section{Saran}

Berdasarkan temuan di lapangan maka Pemerintah dan Pemerintah Daerah dan para pemegang kebijakan penanggulangan bencana untuk tanpa kenal lelah mewujudkan lahirnya masyarakat yang sadar bencana terutama di wilayah yang rawan bencana di sekitar Gunung Sinabung dan Banjarnegara. Hanya dengan membekali masyarakat melalui peningkatan pengetahuan, keterampilan dan kewaspadaan akan terjadinya bencana kembali di suatu hari nanti maka korban jiwa dan harta akan dapat diminimalisasi sebagaimana yang sekarang terjadi pada masyarakat Jepang. Harus diakui, penanganan bencana yang selama ini dilakukan di Indonesia masih tergolong impulsif yaitu fokus pada tindakan pascabencana. Hal-hal yang bersifat mencegah atau menekan angka korban jiwa dan harta jarang sekali diperhatikan. Pemerintah seringkali terjebak di dalam usaha karitatif yaitu terlihat menolong sewaktu bencana terjadi kemudian seiring berjalannya waktu kemudian menganggap penanganan bencana telah usai sementara soal pemulihan dibebankan sepenuhnya menjadi urusan masing-masing warga. 


\section{DAFTAR PUSTAKA}

\section{Jurnal}

Adebukola Yewande Daramola. (2016). Adaptive Capacity and Coping Response Strategies to Natural Disasters: A Study in Nigeria. International Journal of Disaster Risk Reduction. Vol. 15, hlm. 132-147.

Alexander, D.E. (2013). Resilience and Disaster Risk Reduction: An Etymological Journey. Journal Natural Hazards and Earth System Sciences. Vol. 13, hlm. 2707-2716.

Bene, C., dkk. (2012). Resilience: New Utopia or New Tyranny? Reflection about the Potentials and Limits of the Concept of Resilience in Relation to Vulnerability Reduction Programmes. IDS Working Paper 405.

Berkes, F. (2000). Understanding Uncertainty and Reducing Vulnerability: Lessons from Resilience Thinking. Natural Hazards. Vol. 41, No. 2, hlm 283-295.

Blaikie, P., Cannon, T., Davis, I., dan Wisner, B. (2004). At Risk: Natural hazards, People's Vulnerability, and Disasters (second edition). London: Routledge Publication.

Cabinet Office Japan. (2015). White Paper: Disaster Management in Japan 2015.

Carpenter, A. (2014). Resilience in the Social and Physical Realms: Lessons from the Gulf Coast. International Journal of Disaster Risk Reduction.

Carter, W. Nick. (1991). Disaster Management: A Disaster Manager's Handbook. Manila: Asian Development Bank.

Economic and Social Commission for Asia and the Pacific (ESCAP). (2008). Building Community Resilience to Natural Disasters through Partnership. New York: United Nations Publication.

G. Bankoff, D. Frerks, Hilhorst (eds.). (2003). Mapping Vulnerability: Disasters, Development \& People. New York: Routledge.

Harding, J. (2003). Community Coping Strategies. New Delhi: International Strategy for Disaster Reduction.

Holling, C.S. (1973). Resilience and Stability of Ecological System. Journal of Annual Review of Ecological System. Vol. 4, hlm. 1-23.
Jia, Z., dkk. (2010). Mental Health and Quality of Life Survey Among Child Survivors of the 2008 Sichuan Earthquake." Quality Life Research. Vol. 19, hlm.1381- 1391.

Kano, M., dan Bourque L.B. (2008). Correlates of School Disaster Preparedness: Main Effects of Funding and Coordinator Role. Natural Hazards Review. Vol. 9, No. 1, hlm. 49-59.

Leykin, Dmitry, dkk. (2016). The Dynamics of Community Resilience between Routine and Emergency Situations. International Journal of Disaster Risk Reduction. Vol. 15, hlm 125-131.

Marfai, M.A., dkk. (2008). The Impact of Tidal Flooding on a Coastal Community in Semarang, Indonesia. Environmentalist. Vol. 28, No. 3, hlm. 237-248.

Novianty, Anita. (2011). Penyesuaian Dusun Jangka Panjang Ditinjau dari Resiliensi Komunitas Pasca Gempa. Jurnal Psikologi. Vol. 38, No. 1, hlm 30-39.

Paton, D., Millar. M., dan Johnston, D. (2001). Community Resilience to Volcanic Hazard Consequences. Natural Hazards. Vol. 24, hlm 157-169.

Pramono, Rudy. (2016). Perspektif Sosiologis dalam Penanggulangan Bencana. Jurnal Masyarakat dan Budaya. Vol. 18, No. 1, hlm. 81-95.

Samaddar, S., dan N. Okada. (2007). The Process of Community's Coping Capacity Development in the Sumida Ward, Tokyo - A Case Study of Rainfall Harvesting Movement. Annuals of Disaster. Vol. 50, hlm. 205-215.

Saunders dan Becker. (2015). A Discussion of Resilience and Sustainability: Land Use Planning Recovery from the Canterbury Earthquake Sequence, New Zealand. International Journal of Disaster Risk Reduction. Vol. 14, hlm 73-81.

Sriharini. (2009). Manajemen Pasca Bencana Alam: Studi Tentang Rehabilitasi dan Rekonstruksi Rumah Pasca Bencana Alam Gempa Bumi Tanggal 27 Mei 2006 di Kecamatan Banguntapan Kabupaten Bantul Daerah Istimewa Yogyakarta. Yogyakarta: Kurnia Kalam Semesta.

. (2010). Membangun Masyarakat Sadar Bencana. Jurnal Dakwah. Vol. 9, No. 2.

Sriharini. (2006). Pengembangan Kesadaran Masyarakat terhadap Pembangunan Berkelanjutan. Jurnal PMI. Vol. 4, No. 1. 
Sudarmadi, S., dkk. (2001). A Survey of Perception, Knowledge, Awareness and Attitude in Regard to Environmental Problems in a Sample of Two Different Social Groups in Jakarta, Indonesia. Environment, Development and Sustainability. Vol. 3, hlm. 169-183.

Sulastri, A. (2007). Kearifan Lokal Jawa dan Resiliensi Terhadap Trauma Psikologis Pada Korban Selamat Bencana Gempa Bumi di Bantul, Yogyakarta. Kajian Politik Lokal \& Sosial-Humaniora. Vol. 4, No. 1, hlm 146-166.

Takao, Kenji, dkk. (2004). "Factors Determining Residents' Preparedness for Floods in Modern Megalopolises: The Case of the Tokai Flood Disaster in Japan." Journal of Risk Research 7. Vol. 7, No. 8, hlm. 775-787.

Tanaka, Kazuko. (2005). "The Impact of Disaster Education on Public Preparation and Mitigation for Earthquakes: A Cross-Country Comparison Between Fukui, Japan and the San Fransisco Bay Area, California, USA." Applied Geography. Vol. 25, No. 3, hlm. 201-225.

\section{Buku}

Badan Nasional Penanggulangan Bencana. (2017). Buku Pedoman Latihan Kesiapsiagaan Bencana: Membangun Kesadaran dan Kesiapsiagaan Dalam Menghadapi Bencana. Jakarta: Badan Nasional Penanggulangan Bencana.

Bappenas. (2006). Rencana Aksi Nasional Pengurangan Resiko Bencana 2006-2010. Jakarta: Kementerian Negara Perencanaan Pembangunan Nasional/Badan Perencanaan Pembangunan Nasional dengan Badan Koordinasi Nasional Penanggulangan Bencana.

Blaikie, P. Cannon T., Davis, I., dan Wisner, B. (2004). At Risk: Natural Hazards, People's Vulnerability, and Disasters (second edition). London: Routledge Publication.

Carter, W. Nick. (1991). Disaster Management: A Disaster Manager's Handbook. Manila:Asian Development Bank.

Economic and Social Commision for Asia and the Pasific (ESCAP). (2008). Building Community Resilience to Natural Disasters through Partnership. New York: Routledge

G. Bankoff, D. Frerks, Hilhorst (eds). (2003). Mapping Vulnerability: Disasters, Development \& People. New York: Routledge.
Harding, J. (2003). Community Coping Strategies. New Delhi: International Strategy for Disaster Reduction.

Longstaff, P.H., dkk. (2010). Community Resilience: A Function of Resources and Adaptability. New York: Syracuse University.

Palang Merah Indonesia. (1998). Pedoman Penanggulangan Bencana. Jakarta: Markas Besar PMI.

Sriharini. (2009). Manajemen Pasca Bencana Alam: Studi Tentang Rehabilitasi dan Rekonstruksi Rumah Pasca Bencana Alam Gempa Bumi Tanggal 27 Mei 2006 di Kecamatan Banguntapan Kabupaten Bantul Daerah Istimewa Yogyakarta. Yogyakarta: Kurnia Kalam Semesta.

Turnbull, Marilise, dkk. (2013). Toward Resilience: A Guide to Disaster Risk Reduction and Climate Change Adaptation. Warwickshire: Practical Action Publishing Ltd.

\section{Laporan Penelitian}

Dewi, A. (2007). Community-Based Analysis of Coping with Urban Flooding: A Case Study in Semarang, Indonesia. Netherlands: International Institute for Geo-information Science and Earth Observation.

Twigg, John. (2004). "Disaster Risk reduction (Mitigation and Preparedness in Development and Emergency Programming)." Good Practice Review, No. 9, March 2004. London: Overseas Development Institute.

Zein, M. (2010). "A Community Based Approach to Flood Hazard and Vulnerability Assessment in Flood Prone Area: A Case Study in Kelurahan Sewu, Surakarta City, Indonesia." Tesis. Gadjah Mada University and International Institute for Geo-Information Science and Earth Observation.

\section{Internet}

Natural Catastrophes in 2012 Dominated by U.S. Weather Extremes". http://www.worldwatch. org/natural-catastrophes-2012-dominatedus-weather-extremes-0. Diakses tanggal 10 November 2018.

Resiliensi Korban Bencana\}" http://www.ubaya. ac.id/2013/ content/articles_detail/126/ResiliensiKorban-Bencana.html. Diakses tanggal 17 November 2018. 
Why Should Community Coping Mechanism Be the Centre of Disaster Reduction Policy and Practices?" http://www.khurshi dalam. org/ articles. php? $=0$. Diakses tanggal 17 November 2018.

\section{Lain-lain}

Anonim. Ini Penyebab Longsor di Banjarnegara Menurut BNPB. Kompas, 15 Desember 2014.

Betke, Freidhelm. (2002). Assesing Social Resilience Among Regencies and Communities in Indonesia (Discussion paper).

Chandra, A., dkk. (2011). Building Community Resilience to Disasters: A Ways Forward to Enhance National Health Security. USA: RAND Corporation.

Fatwa, Fadillah (2014). Kajian Kebutuhan Erupsi Gunung Sinabung (makalah tidak diterbitkan).

I.Ikhuoria, dkk. (2012). "Assessment of the impact of flooding on farming communities in Nigeria: A case study of Lokoja, Kogi State Nigeria" dalam Proceedings of the Geoinformation Society of Nigeria (GEOSON) \& Nigerian Cartographic Association (NCA) Joint Annual Workshop/ Conference. Hlm. 156-167 